\title{
International Organizations and the Global Social Governance of Pensions
}

\author{
Martin Heneghan
}

\section{INTRODUCTION}

This chapter analyzes the role of International Organizations (IOs) in the global governance of pension policy. The primary purpose of a pension system is to provide income security in old age. A public pension system may seek to offer poverty relief by offering a pension benefit above the poverty line, with additional income in retirement coming from private savings. Public pension systems can also offer more comprehensive benefits, replacing a proportion of a person's income in retirement. The latter is obviously more expensive. In the developed world, most countries have close to universal pension coverage with expenditure across the Organisation for Economic Co-operation and Development (OECD) currently averaging 8.6 percent of the Gross Domestic Product (GDP) (OECD 2017). The precise balance between the state and the market varies from country to country. Within the average expenditure on pensions in the OECD there is a range of different expenditures. In contrast to the

\footnotetext{
M. Heneghan $(\bowtie)$

School of Geography, University of Nottingham, Nottingham, UK e-mail: Martin.Heneghan@nottingham.ac.uk

(C) The Author(s) 2021

K. Martens et al. (eds.), International Organizations in Global

Social Governance, Global Dynamics of Social Policy, https://doi.org/10.1007/978-3-030-65439-9_5
} 
developed world, pension coverage in the developing world is patchier. For example, less than 30 percent of the population in Africa have some form of formal pension coverage (ILO 2017).

In addition to income security in old age, pension policies also have secondary objectives such as developing capital markets to enhance economic growth (Holzmann 1997) or as a way to manage unemployment during economic restructuring (Vanhuysse 2006). As the largest component of government expenditure, they are often a feature of any program aimed at reducing budget deficits or national debt (Güleç 2014). It is therefore no surprise that a number of IOs, beyond those primarily concerned with income protection in old age, have an interest in shaping the pension policies of national governments. The main debates have centered around whether pensions should be offered on a Pay-As-You-Go (PAYG) or a funded basis. PAYG pensions are where the current generation of workers finances the current generation of pensioners through the tax system. A funded system involves individuals setting aside resources for retirement through savings in a private pension plan. A related debate is whether pensions should operate on a defined benefit (DB) or defined contribution (DC) basis. The former involves pensioners receiving a guaranteed proportion of their income in retirement. The latter entails the pension benefit being determined by the performance of the investment from the individual contribution. This transfers the risk to the individual (Barr 2001).

The analysis of the IO population here largely focuses on the International Labour Organization (ILO) and World Bank (WB), as each of these organizations has dominated the global discourse on pension reform at one time or another (Heneghan and Orenstein 2019). The role of the OECD and the European Union (EU) in shaping the pensions agenda through benchmarking is also highlighted. Their role has been more limited due to their smaller membership, but they have still made important contributions to global debates (Orenstein 2008). In addition, various United Nations (UN) agencies have been involved in the recent move toward national social protection floors, which includes pensions, adding more diversity and complexity to the field of IOs involved in pensions (Deacon 2013). This chapter traces the entry of each organization into the field of pensions by outlining the development of three distinct periods in the field. It provides an overview of the IOs involved and the dominant discourses during each period. 


\section{The Organizational Environment and the Intrinsic Features of IOs Involved in the Social Governance of Pensions}

There are three distinct periods in the global social governance of pensions: the golden age of welfare (1945-1970s), the neoliberal era (1979-2008) and the post-global economic crisis era (2009 onward). Each period is characterized by the dominant economic paradigm which has shaped the discourse on pension provision. This paradigm forms the nature of the organizational environment, and in part, determines which actors become involved in the field (Heneghan and Orenstein 2019). This chapter demonstrates that shifts in the dominant global economic paradigm create the space for new IOs to enter the field by providing expertise in line with the new zeitgeist.

In addition to the organizational environment, the unique features of each IO that populate the pension governance environment have shaped the nature of their involvement and the discourses they promote. Their intrinsic features have also determined their ability to respond to a changing environment. For instance, it will be shown that the tripartite nature of the ILO constrained its ability to react to the entry of the WB into the pension reform arena. Intrinsic features also determine the type of involvement an IO has and the nature of its discourse. For example, the WB and ILO have departments with the autonomy to promote specific pension models. In addition, alongside the promotion of pension models they also offer technical assistance to reforming countries. The OECD and EU have a select membership and are therefore reluctant to promote a specific pension model. Instead, they use benchmarking and promote general principles through their cognitive authority (Ervik 2009).

Intrinsic features can determine which source of authority an IO will rely on as a form of social governance in the pensions field. For example, as a bank, the World Bank is able to use its lending capacity to steer the policy agenda of national governments. During the 1980s, the reputation of the World Bank was damaged when-alongside the IMF-it used Structural Adjustment Programmes (SAPs) as a form of conditionality in lending to developing countries. SAPs often involved ordering governments to reduce social expenditure as a way to reduce budget deficits and national debt. These policies proved to be widely unpopular and were abandoned by the World Bank in the 1990s (Stiglitz 2002). The World Bank now prefers to use persuasion rather than coercion as a tool of 
influence (Béland and Orenstein 2013). In addition, IOs are cognizant of the effectiveness of countries owning their development agendas, rather than them being portrayed as protectionist measures of the global north (Deacon 2013). However, the Bank can still use its lending as an additional form of influence. As will be argued, the World Bank was able to induce a number of countries in Central and Eastern Europe to adopt its pension model with the use of loans and technical assistance (Orenstein 2008; Appel and Orenstein 2013). Indeed, the level of indebtedness of a country was argued to be a key source of influence for the World Bank in shaping pension reforms in the region (Müller 1999).

IOs also have power through their moral and cognitive or expert authority (Barnett and Finnemore 2004). The ILO relies largely on moral authority as a form of influence through the soft law of conventions and recommendations. Using a language of universalism, national governments are compelled to sign up to ILO conventions and follow its recommendations to be a 'good global citizen.' The ILO has used a number of these legal instruments to steer pension policies. The moral authority of the ILO is enhanced by its policies which emerge as a consensus between each organ of its tripartite structure-national government representatives, employers' representatives and employees' representatives. In addition, all the IOs involved in global pension governance use their cognitive authority as a source of influence (Orenstein 2008). They each lay claim to pensions expertise, which can compel states to follow their guidance. For example, the OECD produces in-depth reports on the national pension systems of its members in order to compare and contrast the pension systems in each country with the aim of influencing reform through peer learning and emulation (Ebbinghaus 2015).

\section{The IlO and the Global Social Governance of Pensions During the Golden Era}

The ILO has a long history of contributing to the development of pension policies and promoting the expansion of social insurance across the globe. It was an early adopter of the Atlantic Charter (1941) and a proponent of the Beveridge Report (1942), it initiated the Declaration of Philadelphia in 1944 and adopted the UN Declaration of Human Rights in 1948, culminating in the formation of its own Convention 102 on Social Security in 1952. The ILO's pension policies historically consisted of three complimentary strands: the promotion of social security norms across the globe, 
a provider of technical assistance to countries designing a social security system and through the production of social security knowledge in the form of the Costs of Social Security, a key reference point in the field.

Although founded in the aftermath of the First World War, it was while planning for peace at the end of the Second World War that the ILO cemented its position as a global actor in pension policies (Heneghan 2019). On May 10, 1944, while the war was still ongoing, the ILO's 26th International Labour Conference (ILC) in Philadelphia formally established the rights of every human being to social security. The Declaration of Philadelphia requires the ILO to promote the achievement of social security among the nations of the world. The conference was part of an emerging international consensus on the nature and principles of the political, economic and social reconstruction after the war, with the ILO part of a growing movement to foster peace and stability through the use of social policy (Esping-Andersen 1996).

The publication of the Beveridge Report in the United Kingdom in 1942 recast the understanding of income security in old age, popularizing the expression "social security" (Parrott 1992). The ILO had been actively involved in the discussion and articulation of the report. Its core message of "freedom from fear and want" resounded with the desire of the ILO to create a new social settlement that would prevent the conditions for international conflict. From a global perspective, the most important document in pension policy was the Declaration. It was incorporated into the ILO's constitution and formed the cornerstone of its activities in the decades that followed. It recognizes the:

solemn obligation of the International Labour Organisation to further among the nations of the world programmes which will achieve", among others, "the extension of social security measures to provide a basic income to all in need of such protection and comprehensive medical care. (ILO 1944a, Article III (f))

In order to achieve this aim, the Conference adopted two Recommendations, one on income security (Recommendation 67) (ILO 1944b) and one on medical care (Recommendation 69). Recommendations 67 and 69 paved the way for Convention 102 on Social Security (Minimum Standards) that followed shortly after in 1952. The Convention marked a step change in global social security policy, since it introduced the idea of a minimum level of social security that could be attained anywhere in the world 
(Cichon and Hagemejer 2007). It incorporated all the branches of social security, including old age security that had previously been dealt with in separate conventions and recommendations. Convention 102 moved on from defining the classes of people that ought to be protected and instead argued that a specific percentage of the population be covered.

In the years that followed, the ILO set about promoting social security through conferences, the creation of reform templates and the dispatching of consultants. The activities of the ILO were instrumental in the spreading of pension ideas across the globe. In the immediate years after the Declaration most Latin American countries had adopted a pension system by the end of the 1940s. Caribbean countries followed suit in the 1950s and 1960s, with the majority of African countries following later in the 1960s and 1970s (Orenstein 2003).

The Declaration of Philadelphia was the first in a number of international legal instruments that have sought to install social security as a right to every human being. In 1948, the United Nations General Assembly included social security among the rights proclaimed in the Universal Declaration of Human Rights (United Nations 1948). This text was drafted by the United Nations Economic and Social Council (ECOSOC). In 1966, the International Covenant on Economic, Social and Cultural Rights also recognized the rights of everyone to social security (ICESCR 1966). This right to social security formed a central component of the post-war consensus to foster peace and stability. The golden age entailed a considerable expansion of public pension provision across the globe. The consensus on the role of the state in providing income protection in old age would last until the crisis of the Keynesian economic model led to a sustained global challenge to the role of the state in the economy and in society (Table 5.1).

\section{The Neoliberal Economic Order}

The elections of Margaret Thatcher in the United Kingdom in 1979 and Ronald Reagan in the United States in 1980 helped usher in a new economic paradigm. Inspired by Friedrich Hayek (1976) and Milton Friedman (1977), a challenge was mounted against the principles that had underpinned the global economy. These new principles would transform the global discourse on pensions by having an impact on the approach of the World Bank, the OECD and the EU in their pension advocacy. 
Table 5.1 A mapping of IO involvement and the discourses on pension provision 1945-1979

\begin{tabular}{lllll}
\hline Year & $\begin{array}{l}\text { Summary of the } \\
\text { Dominant Discourse }\end{array}$ & IOs Involved & $\begin{array}{l}\text { Method/s of } \\
\text { Influence }\end{array}$ & $\begin{array}{l}\text { Source of } \\
\text { Authority }\end{array}$ \\
\hline \multirow{1}{1945-1979}{} & $\begin{array}{llll}\text { Peace and international } \\
\text { economic prosperity }\end{array}$ & ILO, United & Use of legal & Moral and \\
require a strong welfare & Economic and & instruments such & Expert \\
state. This must include & Social Council & Recommendation & Authority \\
a pension system & (ECOSOC) & 67 on social & \\
offering universal & & security and & \\
coverage with adequate & & Convention 102 & \\
provision operating on a & & on minimum & \\
PAYG basis. & & standards. \\
& & Technical & \\
& & assistance to & \\
& & countries \\
& & designing a & \\
& & pension system. &
\end{tabular}

The privatization of Chile's pension system in 1981, under the authoritarian leadership of Augustus Pinochet, was held up as a beacon for all pension systems by neoliberal policy entrepreneurs. It had been designed by a group of radical reformers nicknamed the 'Chicago Boys'. These had studied under the tutelage of Milton Friedman at the University of Chicago and upon their return to Chile, based themselves at the Pontifical Catholic University of Chile. This institution was the laboratory for a number of neoliberal experiments, of which the most radical was the complete privatization of the public pension system (Borzutzky 2005). The privatization involved diverting pension contributions from taxpayers into individual fully funded pension accounts (IFAs). This represented a significant redrawing of the social contract: from the state to the market and from a collective to individual responsibility. From the mid-1980s up until the Asian Financial Crisis of 1997, the Chilean economy grew at an average annual rate of 7.2 percent (Büchi 2006). The impressive performance of the economy was argued in part to be a result of the development of the capital market the pension privatization had stimulated (Holzmann 1997; World Bank 1994). The Chilean experience would be a constant reference point for organizations that wanted to privatize pension provision. 


\section{The OECD and Pensions}

It was during this period that the OECD began to focus on pension issues (Walker 1990). Its impact was not as far-reaching as the ILO's and did not have the capabilities to be as active as the World Bank in promoting pension privatization. Where the ILO and later the World Bank promoted a message across the globe, the OECD's message was targeted at its members, which consist of the world's most developed nations. Nevertheless, the OECD used its ability to produce authoritative statistical information on pension systems to advocate a shift toward privately funded pensions. In the late 1980s, the OECD began to produce reports on demographic aging and reforms to public pensions (OECD 1988, 2000). These reports built upon earlier critiques of the welfare state from the OECD with an explicit focus on population aging and its implications for the welfare state. By 2000, the OECD was calling for more pension diversification as a way to make public pension systems more sustainable (OECD 2000).

The entry of the OECD into the traditional domain of the ILO wrongfooted the Geneva-based institution during a period of global upheaval. The intrinsic features of the ILO prohibited a robust response to the OECD's critique of the welfare state. The parallel goals of defending and expanding the welfare state in the developed world while building new systems in the developing world stretched the resources of the ILO. The OECD only had to focus on the former. In addition, the ILO was caught up in Cold War tensions between the developed and developing world. It would lead to the United States leaving the organization, cutting its budget by a quarter. The ILO was dealing with considerable internal upheaval just as a rival IO was moving into its traditional field of expertise and influence.

The main contribution of the OECD into the global social governance of pensions has been discursive. It was the first IO to forcefully promote a message that the welfare state was in crisis. It used its expert authority to shift the focus from purely public provision and add to a growing global concern over the sustainability of pension systems and the desirability of diversification. The OECD laid the groundwork for the World Bank to enter the pension reform arena for a message that went beyond the 'rich countries club' of the OECD to the Eastern bloc and the Global South. 


\section{The World Bank Enters the Field}

The collapse of the communist system in Central and Eastern Europe drew the World Bank into the global pensions field. The twin transformation from socialism to market-based capitalism and from authoritarianism to democracy had never been undertaken before. The region was heavily dependent on the expertise of International Financial Institutions (IFIs) (Roaf et al. 2014). It was also starved of capital, which gave the IFIs significant leverage over the reform agenda in the new market economies (Müller 1999). Central and Eastern Europe was uniquely susceptible to neoliberal policy prescriptions given its recent experience with communism. The region was also keen to signal its neoliberal fervor to international investors.

In addition to the susceptibility to neoliberalism and IFI advice, the transformation also had significant consequences for its pension systems. As large sectors of the economy became redundant in the shift away from a planned economy, the pension system was used as a de facto unemployment benefit (Vanhuysse 2006). This led to a sharp increase in the number of pensioners and a subsequent increase in pension expenditure. For example, pension expenditure in Poland reached 15.9 percent of GDP in 1995 (Góra and Rutkowski 2000). This brought pension reform onto the agenda in Central and Eastern Europe (Müller 2003).

Advising middle-income countries with such large pension expenditure was a new experience for the Bank. The publication of Averting the Old Age Crisis in 1994 (Averting hereafter) represented its formal response to t the pension systems of the new post-socialist landscape it was now actively involved in. Its core message was that-due to population aging-public pension systems in the developed world were unsustainable and that every country needed to diversify pension provision through mandatory private savings pillars. Figure 5.1 shows the proposed pension model which entailed three pillars. A public pillar concerned solely with poverty relief, a mandatory private pillar to smooth consumption over the life course and a voluntary pillar for additional savings for those who want a larger income in retirement.

Averting built upon the message on population aging propagated by the OECD and targeted it at developing countries by arguing that most of the growth in the world's old age population would be in developing countries (World Bank 1994, 28). On page one it issues a stern warning to developing countries not to follow the lead of developed countries: 
1

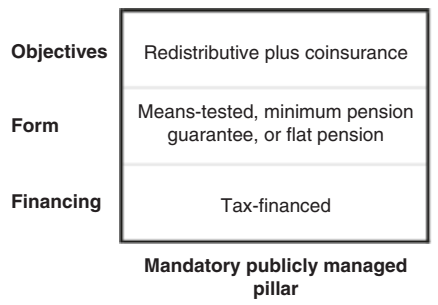

2

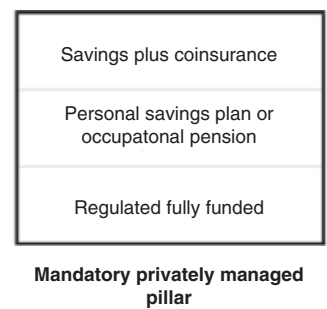

3

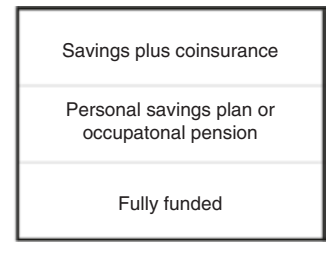

Voluntary pillar

Fig. 5.1 The pillars of old age income security. (Source: World Bank 1994, 15)

At the same time, many developing countries are on the verge of adopting the same programs that have spun out of control in middle-income and high-income countries. (World Bank 1994, 1)

The message on public pension provision was that it required high taxes, which distort labor markets, that in developing countries it was regressive as it redistributed from the poor to the rich, and that it was vulnerable to political manipulation. Meanwhile, private provision was argued to not distort labor markets as it entailed private saving, could produce a more generous pension as returns on investments were greater than economic growth, it was free from political manipulation and could enable developing countries to develop their capital markets.

It was a message that proved to be controversial both inside and outside of the Bank. However, its intrinsic features allowed this particular message to prevail over rival ideas. The World Bank Group consists of the International Bank for Reconstruction and Development (IBRD) which lends to middle-income and developing countries at preferential rates and the International Development Association (IDA) which offers grants to the world's poorest countries. In addition, the World Bank Group is also made up of the International Financial Corporation (IFC) which is concerned with private sector development. The latter arm of the Bank has significant leverage over policy development.

The Averting team came into conflict with consultants in the Eastern European Division who favored parametric reforms to the pension systems of Central and Eastern Europe, such as raising the retirement age and contributions to make the system more sustainable (Barr 1994). 
However, the team behind Averting had powerful support in the form of the financial market sector at the IFC which favored Averting's proposal as it offered the chance to develop capital markets in the new market economies of Central and Eastern Europe. With the internal dispute won by the Averting team it was able to take a coherent message to the rest of the world (Heneghan and Orenstein 2019). Despite its origins in the transitions taking place in Central and Eastern Europe, the message of Averting was aimed at developing countries warning them not to make the mistakes of the developed economies and to only promise modest pension benefits in old age. Its message was therefore far more influential than the message of the OECD which focused its critique on the mature welfare states of its members. The World Bank, in contrast, was seeking to limit the size of developing countries' welfare states before they even existed. Its campaign was highly successful. It led a coalition including the Cato Institute, United States Agency for International Development (USAID) and the pensions industry, persuading 30 countries to adopt its model (Orenstein 2011).

\section{The Response of the ILO}

The entry of a new powerful IO-with considerable resources-into the pensions field spooked the ILO. However, its intrinsic features precluded a formal response (Table 5.2).

The Social Security Department was vehemently opposed to the propositions and policy prescriptions of Averting. Its initial response was lowkey in the form of a journal article in conjunction with the International Social Security Association (ISSA) (Beattie and McGillivray 1995). Yet it was unable to mount a serious challenge to the Bank because other constituents within the ILO's tripartite governing structure were sympathetic to the message of Averting, like the employers' representatives, particularly after lobbying from representatives of the FIAP-International Federation of Pension Funds Administrators. In addition, other constituents were fully supportive of the message in Averting as their countries were adopting the same reforms, such as the Latin American bloc of countries. It would not be until 2000 that the ILO would produce a formal response and by this point it seemed to have largely accepted the message from Averting (Gillion et al. 2000). 
Table 5.2 A mapping of IO involvement and the discourses on pension provision 1979-2000

\begin{tabular}{|c|c|c|c|c|}
\hline Year & $\begin{array}{l}\text { Summary of the } \\
\text { Dominant Discourse }\end{array}$ & $\begin{array}{l}\text { IOs } \\
\text { Involved }\end{array}$ & Method/s of Influence & $\begin{array}{l}\text { Source of } \\
\text { Authority }\end{array}$ \\
\hline 1979-2000 & $\begin{array}{l}\text { Public pension systems } \\
\text { are unsustainable. It is } \\
\text { necessary and } \\
\text { economically desirable } \\
\text { to increase the role of } \\
\text { the market in providing } \\
\text { pensions. }\end{array}$ & $\begin{array}{l}\text { OECD, } \\
\text { World } \\
\text { Bank, } \\
\text { EU }\end{array}$ & $\begin{array}{l}\text { World Bank: Material } \\
\text { influence from the } \\
\text { World Bank through } \\
\text { technical assistance } \\
\text { and loans provided to } \\
\text { implement reforms. } \\
\text { Persuasion in the form } \\
\text { of flagship reports such } \\
\text { as Averting the Old } \\
\text { Age Crisis } \\
\text { OECD and EU: } \\
\text { Benchmarking as a } \\
\text { tool of influence }\end{array}$ & $\begin{array}{l}\text { Expert } \\
\text { Authority }\end{array}$ \\
\hline $1994-2000$ & $\begin{array}{l}\text { A defense of PAYG } \\
\text { pension systems on the } \\
\text { grounds that } \\
\text { marketization places } \\
\text { unnecessary risk on } \\
\text { individuals. }\end{array}$ & $\begin{array}{l}\text { ILO, } \\
\text { ISSA }\end{array}$ & $\begin{array}{l}\text { Debates in academic } \\
\text { and specialist journals. }\end{array}$ & $\begin{array}{l}\text { Moral and } \\
\text { Expert } \\
\text { Authority }\end{array}$ \\
\hline
\end{tabular}

\section{The ILO Changes Direction}

The dominance of the World Bank in the pensions arena forced the ILO to retreat from defending the public pension systems it had promoted. As a reaction to losing its primary role in their promotion, it shifted focus to the developing world where the prevalence of informal labor markets meant that many of the world's poorest had no pensions coverage at all (Reynaud 2005). The ILO launched a campaign to extend coverage to everyone. The theme of its 2001 International Labour Conference was "Extending Social Security to all." The main conclusion from the session was "highest priority should go to policies and initiatives to extend social security to those who have none" (ILO 2001, v). After a protracted internal debate, the ILO settled on the idea of a national social protection floor as its flagship policy (Deacon 2013). A social protection floor entails a minimum level of income security (including pensions) and access to healthcare. 
The campaign for social protection floors was both an internal one, within the ILO, and a wider global campaign. The external campaign began before the social floor was official ILO policy. In 2007, the Director of Social Security at the ILO, Michael Cichon, convened a meeting with representatives from United Nations Department of Social and Economic Affairs (UNDESA), United Nations Children's Fund (UNICEF) and HelpAge International (HAI). The meeting formalized the Coalition for a Global Social Floor. It sought to be a steering committee to bring together a movement for social protection floors under the UN umbrella. It was established in the context of debates around a fairer globalization and global inequalities. In addition, these debates were taking place in parallel with the positive experiences of modern forms of universal social policy in the Global South, such as the conditional cash transfer programs being rolled out in Latin America (Huyse 2017).

\section{Internal Disputes at the Bank}

By the mid-2000s the World Bank was shifting to a more nuanced position on multi-pillar pension reforms. Its intrinsic features allow for internal policy evaluations which can alter policy. Béland and Orenstein (2013) argue that the World Bank is an open system which allows for the contestation of ideas. The challenge to its model first came in the form of a provocative presentation paper titled Rethinking Pension Reform: Ten Myths About Social Security Systems and co-authored by its Chief Economist, Joseph Stiglitz. Here they highlighted a number of micro, macro and political economy assumptions in Averting, which they claimed to be false. Further criticism from within the Bank came from a volume titled Keeping the Promise of Latin America (Gill et al. 2005). This brought attention to the poor coverage in Latin America and exorbitant fees for private pension pillars. The following year, more criticism of the World Bank's pension policy came from a formal internal evaluation, echoing other critiques. In addition, it claimed the benefits of the policy had been oversold and not enough attention had been given to initial conditions before advising reform (Independent Evaluation Group 2006). However, a defense of Averting was published in the form of an updated volume by the Director of Social Protection and Labor in the Bank (Holzmann and Hinz 2005). This volume defended the principle of pension diversification through a multi-pillar system. Yet, developments in the approach of the Bank pointed to a greater role for the state in providing poverty relief to the lifetime 
Table 5.3 A mapping of IO involvement and the discourses on pension provision 2000-2009

\begin{tabular}{|c|c|c|c|c|}
\hline Year & $\begin{array}{l}\text { Summary of the } \\
\text { Dominant Discourse }\end{array}$ & IOs Involved & $\begin{array}{l}\text { Method/s of } \\
\text { Influence }\end{array}$ & $\begin{array}{l}\text { Source of } \\
\text { Authority }\end{array}$ \\
\hline \multirow[t]{2}{*}{ 2000-2009 } & $\begin{array}{l}\text { Open internal debate on } \\
\text { the merits and drawbacks } \\
\text { of multi-pillar pension } \\
\text { reform. }\end{array}$ & $\begin{array}{l}\text { ILO and World } \\
\text { Bank }\end{array}$ & $\begin{array}{l}\text { Internal reports } \\
\text { and pensions } \\
\text { volumes }\end{array}$ & Expert \\
\hline & $\begin{array}{l}\text { Extending coverage of } \\
\text { pensions to the } \\
\text { developing world is a } \\
\text { policy priority. } \\
\text { Embryonic discussions } \\
\text { of a social protection } \\
\text { floor. }\end{array}$ & $\begin{array}{l}\text { ILO, World } \\
\text { Bank, } \\
\text { UNDESA, } \\
\text { UNICEF, ISSA }\end{array}$ & $\begin{array}{l}\text { ILC Conference, } \\
\text { policy reports, } \\
\text { steering groups }\end{array}$ & $\begin{array}{l}\text { Expert, } \\
\text { Moral }\end{array}$ \\
\hline
\end{tabular}

poor. In that sense it began the process of the World Bank beginning to focus on coverage through the public system, rather than diversification through privatization (Table 5.3).

\section{The Global Economic Crisis and Its Impact on the Global Pension Environment}

At the onset of the global economic crisis, most countries that had adopted the World Bank's multi-pillar pension reforms either halted them, drastically reduced the private element or completely abandoned them. This was largely a result of the fiscal implications of implementing a multi-pillar reform (Orenstein 2011; Sokhey 2017). As a result, the crisis significantly altered the IO global social governance environment of pensions. It had the twin impact of damaging the expert authority of the World Bank and allowed the ILO to reassert itself into the pensions debate.

Beginning with the ILO, the immediate post-crisis era of cooperation between the nation states that comprise the G20 had implications for the Geneva-based organization. Internally, the crisis helped to create a consensus for the ILO's flagship policy of national protection floors. It was formalized with the passing of Recommendation 202 by the ILC in 2012. On old age income security, the social protection floor policy states that: 
all residents in old age and all residents with a disability to the extent that it excludes them from gainful activity enjoy income security at least at a nationally defined minimum level, through benefits in cash or in kind for old age and disability. (ILO 2011, 21)

Externally, as governments around the world intervened in their economies to stimulate aggregate demand in the economy and rescue insolvent banks, the role of social security as an automatic stabilizer in the macro economy was highlighted (IILS 2011). As a result of this, the ILO was invited to the top table of governance at the G20 to report on how its role could be broadened across the globe to embed its stabilizing function in the global economy (Deacon 2013).

In light of the crisis, the UN developed a series of coordinated responses to secure economic recovery and better protect the world's population against a future downturn (Deacon 2013). The Social Protection Floor Initiative (SPF-I) was developed by the Chief Executives Board of the UN (UNCEB). Its aim was to explore methods for IOs to support countries that wanted to expand social protection in their societies. It was to be chaired by the ILO and World Health Organization (WHO) with responsibilities divided between the ILO focusing on income security (including old age security) and the WHO focusing on basic healthcare provision. The SPF-I invited the former president of Chile (Michelle Bachelet) to write a report on social protection floors. Its publication in 2011 coincided with the French Presidency of the G20. Nicholas Sarkozy was sympathetic to the idea of a social protection floor which helped to keep it on the G20 policy agenda. The Bachelet Report called for a formal interagency development board to coordinate the disparate activities on social protection. This was heeded by the G20 as the Development Working Group set up the Social Protection Inter-Agency Cooperation Board (SPIAC-B). This board is chaired by the ILO and World Bank and meets biannually to coordinate strategies to expand social protection coverage to the developing world.

The crisis also created the conditions for the World Bank to abandon its campaign for pension privatization and work much more closely with the ILO to focus more exclusively on social pensions in the developing world. The impact of the crisis on pension funds was almost immediate, with US\$5 trillion dollars wiped off pension assets in the early crisis period (Keeley and Love 2010). This damaged the performance of the fledgling 
pension systems of Central and Eastern Europe just as the first beneficiaries from the World Bank-led reforms were due to draw a pension. This gave domestic opponents of the pension system ammunition to attack the desirability of the reforms.

The fiscal impact of the crisis was an even greater blow to the World Bank's pension model. The early Keynesian activism of national governments gave way to fiscal conservatism as the crisis rolled on. Balancing budget deficits became the central target of policy makers as an era of austerity took hold and markets turned on the countries of Southern Europe for their debt levels. This had important implications for the pension systems of the countries in Central and Eastern Europe. The partial privatization of the pension system involved diverting contributions that previously went to the PAYG public pillar into individually funded accounts. This left a funding deficit in the public pillar-a transition costto pay the current generation of retirees' pensions. The transition costs were significant and primarily financed by borrowing. For example, the transition costs in the pension system in Poland were as high as 1.8 percent of GDP (Bielawska et al. 2016).

A further complication was the role of the EU in the governance of the Central and Eastern European pension systems. Like the OECD, the EU does not promote a global pension model, its membership is limited by geography and its members have a broad range of pension systems. Similar to the OECD, its governance of pensions has implications beyond its members. In the late 1990s, the EU became increasingly involved in pension policy for a similar reason to the OECD - its impact on the wider macro economy. This was given further impetus in the Lisbon process which had explicit goals for raising the employment of older workers (Ebbinghaus 2015). The main form of governance is 'soft governance' whereby the EU produces common indicators and benchmarks-through its open method of coordination-with the aim of countries learning from each other, with emulation driving a process of convergence. However, it is within the financial constraints placed on members of the European Monetary Union (EMU) where the EU had an indirect but significant impact on global pension policy.

The accession of Central and Eastern European countries into the EU meant they were bound by the Maastricht Criteria on government borrowing. This stipulates that EU member states cannot run budget deficits larger than 3 percent of GDP and national debt must be below 60 percent 
of GDP. This made reversing the World Bank's pension model politically attractive. The poor performance of the pension funds had generated dissent. Renationalizing the pension system had the benefit of immediately reducing the deficit by diverting the private contributions back into the public pillar. Moreover, renationalizing the system meant the government was able to seize the accumulated pension assets. For example, in the case of Hungary, this entailed the national debt reducing by 10 percent of GDP overnight (Simonovits 2011).

As country after country reversed the World Bank's pension model it significantly dented the reputation of the World Bank as an expert authority on pensions. In addition, the Bank had also lost its leverage in Central and Eastern Europe as the region was no longer dependent on its finance. The region's integration into the global economy meant that it had access to other sources of finance, such as the European Bank for Reconstruction and Development (EBRD) and Foreign Direct Investment (FDI). As a result of waning influence in the region and across other middle-income countries, demand for World Bank pension assistance now primarily comes from developing countries. These countries have very different needs and are more likely to require assistance with designing a public pension system to provide poverty relief.

The failure of the World Bank's multi-pillar model-particularly in the post-communist countries where it was heavily involved-alongside a demand for the World Bank to assist in extending pension coverage has meant the alignment of the ILO and World Bank agendas. ${ }^{1}$ The World Bank has adopted the language promoted by the ILO on social protection floors and its primary purpose in the field now is to expand the coverage of social protection in the developing world. The ILO was successful in its efforts to influence the UN Sustainable Development Agenda (Huyse 2017). This agenda will largely determine the orientation of developmentrelated resources both globally and nationally. After lobbying by the ILO, social protection was integrated into 5 of the 17 sustainable development goals (Huyse 2017). This means that social protection is now a key focus of the development agenda for many years to come. Notably, goal 1.3

\footnotetext{
${ }^{1}$ Despite this alignment, the ILO published a scathing critique of the World Bank's pension model in late 2018 in its evaluation of the pension privatization campaign, labeling it a failure (Ortiz et al. 2018).
} 
explicitly mentions social protection floors. It culminated in the Global Partnership for Universal Social Protection announced at the UN General Assembly in 2016, which is to be jointly developed by the ILO and World Bank.

The current global social governance of pensions is characterized by cooperation between the two major IOs in the field. They jointly chair the SPIAC-B which has coordinated social protection policy including pensions. One of the major outcomes of the board to date has been the production of a set of practical tools that help countries improve their social protection system by analyzing its strengths and weaknesses and offering policy options for further action. This toolkit was jointly developed by the World Bank, ILO, OECD, EU, United Nations Development Programme (UNDP), International Council on Social Welfare (ICSW), UNICEF and a number of bilateral donors and non-governmental organizations (NGOs). This type of tool characterizes the nature of global social governance in pensions. Although the World Bank and ILO will still assist individual countries with their pension reforms, the global debate takes place largely within the broader social protection agenda. This means a number of additional IOs, such as the ones listed above, have been loosely drawn into the field of pensions.

The analysis for this chapter has largely focused on activity at the headquarters of the IOs involved. Further research is needed in field offices where there is considerable discretion and autonomy. This may be consequential because though both the World Bank and ILO use a similar discourse on social protection, key differences in interpretation remain. In particular, the interpretation of the term universal is contested. For the World Bank it simply means everyone having some form of coverage, for the ILO it means everyone having the same coverage. This means that previous debates on the role of means-testing may resurface. In a recent report, the World Bank $(2018,83)$ argued that means-testing was more effective at reducing poverty in old age social pensions. For now, the rolling out of coverage to those who have none fosters close collaboration between the two organizations, since both are primarily focused on creating coverage. However, these differences in interpretation and orientation may have implications for activities in the field (Table 5.4). 
Table 5.4 A mapping of IO involvement and discourses on pension provision 2009 onward

\begin{tabular}{|c|c|c|c|c|}
\hline Year & $\begin{array}{l}\text { Summary of the } \\
\text { Dominant } \\
\text { Discourse }\end{array}$ & IOs Involved & Method/s of Influence & $\begin{array}{l}\text { Source of } \\
\text { Authority }\end{array}$ \\
\hline $\begin{array}{l}2009- \\
\text { present }\end{array}$ & $\begin{array}{l}\text { National Social } \\
\text { Protection Floors } \\
\text { and extending } \\
\text { coverage to the } \\
\text { developing world. }\end{array}$ & $\begin{array}{l}\text { ILO, World } \\
\text { Bank, UNDP, } \\
\text { ISSA, } \\
\text { UNICEF, } \\
\text { OECD, EU, } \\
\text { ICSW }\end{array}$ & $\begin{array}{l}\text { SPIAC-B, } \\
\text { Recommendation } 202 \\
\text { on national social } \\
\text { protection floors, social } \\
\text { protection toolkits. }\end{array}$ & $\begin{array}{l}\text { Delegated } \\
\text { authority from } \\
\text { the G20, Moral } \\
\text { Authority and } \\
\text { Expert authority }\end{array}$ \\
\hline
\end{tabular}

\section{Conclusion}

This chapter has outlined the global social governance of pensions undertaken by IOs. It has shown how the field has been characterized by both contestation and cooperation between the two main IOs in the field. It is clear that major shifts in the global economic paradigm have been the main driving force for change in the organizational environment of IOs in the field. It has allowed new actors such as the World Bank to enter the field and also determined the varying power of the ILO in having influence over the international agenda. In addition to the two main actors in the field, the chapter has also demonstrated the partial roles played by other powerful IOs in shaping the discourse, including the role of the EU in undermining the multi-pillar pension model in Central and Eastern Europe - the region that was most associated with wholeheartedly embracing the message of the World Bank on pension provision. How IOs respond to this changing environment has also been shown to be determined in part by their intrinsic features. These features can act as a constraining force, which was the case with the ILO. In addition, the intrinsic features of the organization may allow for policy debate that can lead to shifting positions on the policy stance of the organization.

\section{REFERENCES}

Appel, Hilary, and Mitchell A. Orenstein. 2013. "Ideas Versus Resources Explaining the Flat Tax and Pension Privatization Revolutions in Eastern Europe and the Former Soviet Union." Comparative Political Studies 46 (2): 123-152. 
Büchi, Hernán. 2006. "How Chile Successfully Transformed Its Economy." The Heritage Foundation. September 18. https://www.heritage.org/internationaleconomies/report/how-chile-successfully-transformed-its-economy. Accessed February 2019.

Barnett, Michael, and Martha Finnemore. 2004. Rules for the World. New York: Cornell University Press.

Barr, Nicholas. 1994. Labor Markets and Social Policy in Central and Eastern Europe: The Transition and Beyond. Washington, DC: World Bank.

Barr, Nicholas. 2001. The Welfare State as Piggy Bank. Oxford: Oxford University Press.

Beattie, Roger, and Warren McGillivray. 1995. “A Risky Strategy: Reflections on the World Bank Report Averting the Old Age Crisis." International Social Security Review 48 (3-4): 5-22.

Béland, Daniel, and Mitchell A. Orenstein. 2013. "International Organizations as Policy Actors: An Ideational Approach.” Global Social Policy 13 (2): 125-143.

Bielawska, Kamila, Agnieszka Chłoń-Domińczak, and Dariusz Stańko. 2016. Retreat from Mandatory Pension Funds in Countries of the Eastern and Central Europe in Result of financial and Fiscal Crisis: Causes, Effects and Recommendations for Fiscal Rules. Warsaw: Warsaw School of Economics.

Borzutzky, Silvia. 2005. "From Chicago to Santiago: Neoliberalism and Social Security Privatization in Chile." Governance 18 (4): 655-674.

Cichon, Michael, and Krzysztof Hagemejer. 2007. "Changing the Development Policy Paradigm: Investing in Social Security Floor for All.” International Social Security Review 60 (2-3): 169-196.

Deacon, Bob. 2013. Global Social Policy in the Making. Bristol: Policy Press.

Ebbinghaus, Bernhard. 2015. "The Privatization and Marketization of Pensions in Europe: A Double Transformation Facing the Crisis." European Policy Analysis, Spring: 56-73.

Ervik, Rune. 2009. "Policy Actors, Ideas and Power: EU and OECD Pension Policy Recommendations and National Policies in Norway and the UK." In The Role of International Organizations in Social Policy: Ideas, Actors and Impact, edited by Rune Ervik, Nanna Kildal and Even Nilssen, 138-164. Cheltenham: Edward Elgar.

Esping-Andersen, Gøsta. 1996. Welfare States in Transition: National Adaptations in Global Economies. London: Sage.

Friedman, Milton. 1977. "Nobel Lecture: Inflation and Unemployment." Journal of Political Economy 85 (3): 451-472.

Güleç, Asl1. 2014. “The Politics of Pension Reform in Greece and Turkey: International Institutions as External Determinants of Adjustments." Global Social Policy 14 (1): 72-90. 
Gill, Indermit, Truman G. Packard, and Juan Yermo. 2005. Keeping the Promise of Social Security in Latin America. Washington DC: World Bank.

Gillion, Colin, John A. Turner, Clive Bailey, and Denis Latulippe. 2000. Social Security Pensions: Development and Reform. Geneva: International Labour Organisation.

Góra, Marek, and Michal Rutkowski. 2000. “The Quest for Pension Reform: Poland's Security through Diversity." https://deepblue.lib.umich.edu/bitstream/handle/2027.42/39670/wp286.pdf? sequence=3.

Accessed June 22, 2020.

Hayek, Friedrich A. 1976. The Road to Serfdom. London: Routledge.

Heneghan, Martin. 2019. Setting the Agenda: The World Bank and International Labour Organisation's Battle to Shape Global Pension Policy. Doctoral Dissertation, University of Sheffield

Heneghan, Martin, and Mitchell A. Orenstein. 2019. "Organizing for Impact: International Organizations and Global Pension Policy." Global Social Policy 19 (1-2): 65-86.

Holzmann, Robert. 1997. "Pension Reform, Financial Market Development, and Economic Growth: Preliminary Evidence from Chile." IMF Staff Papers 44 (2): 149-178.

Holzmann, Robert, and Richard Hinz. 2005. Old-age Income Support in the 21st century: An International Perspective on Pension Systems and Reform. Washington DC: World Bank.

Huyse, Huib. 2017. Independent Evaluation of the ILO's strategy and Actions for Creating and Extending Social Protection Floors, 2012-2017. Geneva: International Labour Office.

ICESCR. 1966. International Covenant on Economic, Social and Cultural Rights. December 16. http://www.equalrightstrust.org/ertdocumentbank// ICESCR.pdf. Accessed May 2018.

IILS. (2011). A Review of Global Fiscal Stimulus. International Labour Organization, International Institute for Labour Studies and EC Discussion Series. International Labour Office.

ILO. 1944a. "ILO Declaration of Philadelphia." International Labour Organization. http://blue.lim.ilo.org/cariblex/pdfs/ILO_dec_philadelphia. pdf. Accessed May 2018.

ILO. 1944b. "Income Security Recommendation, 1944 (No. 67)." International Labour Organisation. May 26. Accessed August 2018. https://www.ilo.org/dyn/ normlex/en/f?p=NORMLEXPUB:12100:0::NO::P12100_ILO_CODE:R067.

ILO. 2001. Social security: A new consensus. International Labour Organisation, Geneva: International Labour Office.

ILO. 2011. Social Security for Social Justice and a Fair Globalization. Geneva: International Labour Organization. 
ILO. 2017. World Social Protection Report 2017-19: Universal Social Protection to Achieve the Sustainable Development Goals. Geneva: International Labour Office.

Independent Evaluation Group. 2006. Pension Reform and the Development of Pension Systems: An Evaluation of World Bank Assistance. Washington, DC: World Bank.

Keeley, Brian, and Patrick Love. 2010. OECD Insights From Crisis to Recovery: The Causes, Course and Consequences of the Great Recession. Paris: OECD Publishing.

Müller, Katharina. 1999. The Political Economy of Pension Reform in CentralEastern Europe. Cheltenham: Edward Elgar.

Müller, Katharina. 2003. Privatising Old-Age Security: Latin America and Eastern Europe Compared. Cheltenham: Edward Elgar.

OECD. 1988. Reforming Public Pensions. Paris: OECD.

OECD. 2000. Reforms for an Ageing Society. Paris: OECD.

OECD. 2017. Pensions at a Glance 2017: OECD and G20 indicators. Paris: OECD

Orenstein, Mitchell A. 2003. "Mapping the Diffusion of Pension Innovation." In Pension Reform in Europe: Process and Progress, edited by Robert Holzmann, Mitchell Orenstein and Michal Rutkowski, 171-194. Washington, DC: World Bank.

Orenstein, Mitchell A. 2008. Privatizing Pensions: The Transnational Campaign for Social Security Reform. New Jersey: Princeton University Press.

Orenstein, Mitchell A. 2011. "Pension Privatization in Crisis: Death or Rebirth of a Global Policy Trend?” International Social Security Review 64 (3): 65-80.

Ortiz, Isabel, Fabio Durán-Valverde, Stefan Urban, Veronika Wodsak, and Zhiming Yu. 2018. Reversing Pension Privatizations: Rebuilding Public Pension Systems in Eastern Europe and Latin America. Geneva: International Labour Organization.

Parrott, Alec L. 1992. "Social Security: Does the Wartime Dream Have to Become a Peacetime Nightmare?" International Labour Review 131: 367-386.

Reynaud, Emanuel. 2005. "Social Security For All: Global Trends and Challenges." Comparative Labor Law and Policy Journal 27 (2): 123-150.

Roaf, James, Ruben Atoyan, Bikas Joshi, and Krzysztof Krogulski. 2014. Regional Economic Issues - Special Report 25 Years of Transition: Post-Communist Europe and the IMF. Washington, DC: International Monetary Fund.

Simonovits, Andras. 2011. "The Mandatory Private Pension Pillar in Hungary: An Obituary." International Social Security Review 64 (3): 81-98.

Sokhey, Sarah Wilson. 2017. The Political Economy of Pension Policy Reversal in Post-Communist Countries. Cambridge: Cambridge University Press.

Stiglitz, Joseph. 2002. Globalisation and its Discontents. London: Penguin Books. 
United Nations. 1948. United Nations Universal Declaration of Human Rights 1948. http://www.jus.uio.no/lm/un.universal.declaration.of.human.rights. 1948/portrait.a4.pdf. Accessed May 2018.

Vanhuysse, Pieter. 2006. Divide and Pacify. New York: Central European University Press.

Walker, Alan. 1990. “The Economic 'Burden' of Ageing and the Prospect of Intergenerational Conflict." Ageing \& Society 10 (4): 377-396.

World Bank. 1994. Averting the Old Age Crisis: Policies to Protect the Old and Promote Growth. New York: Oxford University Press.

World Bank. 2018. The State of Social Safety Nets. Washington, DC: International Bank for Reconstruction and Development.

Open Access This chapter is licensed under the terms of the Creative Commons Attribution 4.0 International License (http://creativecommons.org/licenses/ by $/ 4.0 /$ ), which permits use, sharing, adaptation, distribution and reproduction in any medium or format, as long as you give appropriate credit to the original author(s) and the source, provide a link to the Creative Commons licence and indicate if changes were made.

The images or other third party material in this chapter are included in the chapter's Creative Commons licence, unless indicated otherwise in a credit line to the material. If material is not included in the chapter's Creative Commons licence and your intended use is not permitted by statutory regulation or exceeds the permitted use, you will need to obtain permission directly from the copyright holder.

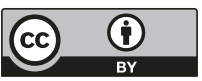

